This item was submitted to Loughborough's Research Repository by the author.

Items in Figshare are protected by copyright, with all rights reserved, unless otherwise indicated.

\title{
The Beijing 2008 olympics: Examining the interrelations of China, globalization, and soft power
}

PLEASE CITE THE PUBLISHED VERSION

http://dx.doi.org/10.1017/S1062798714000684

\section{PUBLISHER}

(c) Cambridge University Press (CUP)

VERSION

AM (Accepted Manuscript)

\section{PUBLISHER STATEMENT}

This work is made available according to the conditions of the Creative Commons Attribution-NonCommercialNoDerivatives 4.0 International (CC BY-NC-ND 4.0) licence. Full details of this licence are available at: https://creativecommons.org/licenses/by-nc-nd/4.0/

\section{LICENCE}

CC BY-NC-ND 4.0

\section{REPOSITORY RECORD}

Giulianotti, Richard. 2019. "The Beijing 2008 Olympics: Examining the Interrelations of China, Globalization, and Soft Power". figshare. https://hdl.handle.net/2134/21889. 


\title{
(ORIGINAL MANUSCRIPT)
}

This is the Author's Original Manuscript in its final and definitive form. The Version of Record can be found via the following reference:

Giulianotti, R. (2015) The Beijing 2008 Olympics: Examining the Interrelations of China,

Globalization, and Soft Power, European Review, 23(2), 286-296. Available:

http://journals.cambridge.org/action/displayAbstract?fromPage $=$ online\&aid $=9621758 \&$ fileId $=$ $\underline{\mathrm{S} 1062798714000684}$

\begin{abstract}
About the Author
Richard Giulianotti is Professor of Sociology at Loughborough University, UK, and Professor II at Telemark University College, Norway. His main research interests are in the fields of sport, globalization, mega-events, migration, development and peace, crime and deviance, and research methods. He is the author of Globalization and Football (Sage, 2009; with Roland Robertson), Ethics, Money and Sport (Routledge, 2006; with Adrian J. Walsh), Sport: A Critical Sociology (Polity, 2005), and Football: A Sociology of the Global Game (Polity, 1999). He has also acted as guest coeditor of special issues of the journals British Journal of Sociology (2012), Global Networks (2007) and Urban Studies (2011), and he has published articles in many leading social science journals. His books and articles have been translated into German, Italian, Korean, Norwegian, Portuguese, Serbian, and Spanish. He is currently leading a major project, funded by the UK Economic and Social Research Council, investigating the 'sport for development and peace sector' at global level.
\end{abstract}


The Beijing 2008 Olympics:

Examining the Interrelations of China, Globalization, and Soft Power

\author{
Richard Giulianotti \\ School of Sport, Exercise and Health Sciences, Loughborough University, UK \\ Telemark University College, Norway \\ Email: < R.Giulianotti@lboro.ac.uk>
}

\begin{abstract}
This article explores the national and global significance and impact of Beijing's hosting of the 2008 summer Olympic Games. The discussion is organized into four main parts. First, I locate the 2008 Beijing Olympics in the context of wider processes of globalization; in particular, I explore how China 'glocalized' the Olympics, by giving the event distinctive meanings that were then experienced by global television audiences. Second, I employ the concept of 'soft power' to explore how, in hosting the event, China sought to advance its international influence and appeal; I introduce the concept of 'soft disempowerment' to examine how there may have been some negative impacts for China in staging the Olympics. Third, I discuss issues of security surrounding the Beijing Olympics, given the growing focus on such questions for sport mega-events in general following the 9/11 attacks in 2001. Fourth, I outline some of the key issues regarding sporting legacies for China, following the 2008 Olympics, with particular reference to Chinese football.
\end{abstract}

In the summer of 2008, the city of Beijing staged the Olympic Games followed by the Paralympic Games. In his speech at the Olympic closing ceremony, the President of the International Olympic Committee, Jacques Rogge, argued that the event had advanced international understanding between the hosts and other societies: "Through these Games, the world learned more about China, and China learned more about the world” (BBC News, 24 August 2008).

In the discussion that follows, I explore the significance of Beijing's hosting of the Olympics with regard to four main issues and themes. First, I examine this event in the context of contemporary globalization; in particular, I utilize the theory of 'glocalization' to assess how China adapted the Olympics to give it particular cultural meanings before global audiences. Second, I consider the event with regard to China's pursuit of soft power; I introduce the concept of 'soft disempowerment' to refer to how, in a competitive international context, there is potential for cities and nations to experience some negative effects in hosting international mega-events. Third, issues of security have acquired heightened importance at mega-events since the early 2000s, and I discuss this question with respect to Beijing 2008. Finally, I consider sport legacy issues following the Beijing games, notably in regard to the development of elite-level football in China.

\title{
Globalization and glocalization
}


Sport mega-events may be regarded as particularly powerful manifestations of contemporary globalization. In economic terms, these events are multi-billion-dollar festivals, involve a global array of corporate sponsors, and enable host cities and nations to 'sell themselves' before potential investors, customers and tourists. In social terms, across their full duration, sport mega-events attract worldwide television audiences that are measured in many billions. In political terms, these events attract politicians from across the world, particularly to the Opening Ceremonies, while also tending to generate different forms of political conflict, protest and opposition. These events also engage diverse national societies in common cultural activities in the form of specific sporting disciplines.

The concept of glocalization is a particularly fruitful one for exploring how mega-events such as the Olympics or World Expos represent particular kinds of cultural globalization. Glocalization, the concept, was introduced to the social sciences by Roland Robertson, and refers to the complex interplays between local and global processes in regard to globalization. ${ }^{1}$ Glocalization thus enables us to understand globalization as an essentially dynamic, continuous and open-ended process.

Two important points arise here in this context. First, glocalization rejects the common assumption that the local and the global are opposed to each other; instead, we should recognize that the local and the global are deeply interdependent. Hence, we may see how 'the local' is constantly shaped and influenced by 'the global'. For example, in China, we may say that local or national cultural identities, customs, languages, and belief-systems are constantly responding and adapting, and being reshaped or reaffirmed, through interaction with other cultural phenomena at transnational level.

Second, this interplay between the local and the global may have different consequences or results in regard to the question of cultural similarities and cultural differences. In some contexts, glocalization may be manifested by cultural convergence, sameness or homogenization, as different societies come to share common ground in the cultural sense, as they engage with specific cultural phenomena (such as sport or popular music) in similar ways. In other circumstances, glocalization involves cultural divergence, difference or heterogenization, as different societies promote 'unique' cultural practices and identities; or, these societies may advance distinctive adaptations and interpretations of cultural phenomena that are otherwise widespread at the transnational level.

Often, we find that processes of convergence are associated with cultural forms (such as specific forms or genres of art, literature, music, sport, and media), or the formal institutions and organizations that control these cultural practices. Conversely, divergence tends to be more evident in regard to cultural content; that is, in how particular cultural activities are practised, interpreted, and aestheticized by different societies. ${ }^{2}$ Overall, this mix of convergence and divergence, or homogenization and heterogenization, in global culture may be viewed as representing the duality of glocality.

Processes of glocalization were central to the cultural construction of the 2008 Olympic Games in Beijing. On one hand, the broad form and structure of Beijing 2008 mirrored those at other Olympic Games: thus, there was the pre-event torch relay, beginning in Olympia in Athens and concluding in the host city; the 17 day duration of the tournament, marked by the Opening and Closing Ceremonies; the specified Olympic venues; the specified Olympic sports, ranging from archery to wrestling; the accredited officials, athletes, coaches, media representatives, venue employees, volunteers, and security personnel; and, the list of 
recognized competing nations, and final medal table. Like other host cities, in terms of the glocalization of cultural forms, Beijing 2008 was inevitably required to draw on global technologies, methods, standards and forms of expertise, while also being required to follow particular guidelines by global governing organizations which ultimately control such events. On the other hand, the global mega-event becomes rather more interesting when its content is creatively adapted or transformed by the hosts. Thus, we find that the host nation thrives in particular sports, for example as China did so in diving, gymnastics, table tennis, and weightlifting; in some sports, notably table tennis, particular Chinese techniques and skills are showcased and come to dominate at global level. Moreover, we find that the Beijing Games were distinctive in terms of their venue design, expenditure (notably on security), and key imagery at major ceremonies.

The opening ceremonies of mega-events serve to crystallize the duality of glocality, combining convergence and divergence. For example, opening ceremonies may contain spectacular celebrations of particular kinds of nationhood, while also engaging with global themes such as Olympism, peace and development. Moreover, such events also provide the world with a first look at the host stadium, which itself is wrapped in glocal meaning.

The duality of glocality is implied in the insightful reading by Wang Ning of the opening ceremony at the Beijing Games. For Wang, this glocal occasion featured,

the unprecedented highlight of Confucian ideas which are certainly Chinese and local, but on the other hand, all these are realized by means of postmodern high technologies in sound, light, and electricity which are introduced from the West and thus global... It proves that globalization cannot be achieved unless it is located in a certain cultural soil or localized in a certain civilization. ${ }^{3}$

The ceremony was glocalized in terms of mixing local and global messages and themes - in effect, using a Chinese lens to adapt a global event before both the local/Chinese and global audiences. Key themes during the ceremony centred on peace and harmony, thereby activating both 'traditional' Confucian or Chinese values (while reaching beyond China's modern political system), and positive global values associated in part with the Olympic movement. ${ }^{4}$ In addition, the ceremony played substantially to the themes of technology and industry, thus pointing back to the long history and achievements of Chinese civilization and forward towards China's rapid industrial development.

Moreover, we might note that the opening ceremony was famously staged in the newly constructed Beijing National Stadium which itself showcased distinctive glocal features. The stadium - popularly known as the 'Bird's Nest' due to its unique architectural features - had been designed by the globally-renowned Swiss company Herzog \& de Meuron, whose other commissions included Tate Modern in London, the Walker Arts Center in Minneapolis, the Allianz Arena football stadium in Munich, and the Caixa Forum in Madrid; in order to enhance the local flavour, the stadium designers were supported by the Chinese artist Ai Weiwei, who acted as a consultant on the project. Thus, overall, the Beijing Games crystallized glocal processes of convergence and divergence within sport and, more broadly, in regard to China's contemporary engagement with globalization.

Beijing 2008 Olympics, soft power and 'soft disempowerment' 
A second set of issues concerns how global mega-events provide host cities and nations with the opportunity to leverage and to glocalize forms of soft power on the transnational stage. The term 'soft power' was initially advanced by the American political scientist, Joseph Nye, who defined this in terms of "the ability to get what you want through attraction rather than coercion or payment". ${ }^{5}$ Soft power thus contrasts with hard power (such as military intervention), and reflects the more subtle ways in which international political influence is secured, although in reality both categories of power are often interlaced. The term soft power has long slipped from academic circles into far wider usage across the public sphere. Culture represents a key field for the pursuit and exercise of soft power, notably through sport, the arts, education, and media. ${ }^{6}$

According to the Chinese international relations expert Pang Zhongying (2008), the Beijing Olympics marked 'a milestone in China's exploration of soft power'. 7 For China, soft power was pursued and exercised in a variety of ways around the 2008 Olympics. For example, the Beijing Games helped to embed China more fully within international society, while also providing a unique occasion through which the outside world might be drawn towards the event's hosts. In the more optimistic view, as advanced by Pang, the Olympics enabled China to strengthen its links with competing nations, in particular the United States and also the developing world.

The Games also crystallized China's stronger engagement with transnational sport and culture. Chinese athletes have become more prominent in world-leading leagues, notably five players who have broken into the NBA in North America since 2001. In a broader sense, the Olympics were intended inter alia to boost China's soft power in terms of image and appeal as a highly modern, efficient and increasingly prosperous nation; as the home to a sophisticated ancient culture and civilization; and, as an attractive destination for international tourists, professionals and students.

A further point to consider here is the interrelationships between 'city-branding' or 'nation-branding' and soft power. The hosting of major sport teams or sport mega-events may be seen as one important way through which cities and nations may brand their identities, often in post-industrial contexts, within the global marketplace of investors, business partners, tourists, and other consumers. ${ }^{8}$ The Beijing Games was no exception here, in terms of offering the host city and nation the opportunities to advance their place branding before global visitors and wider audiences. However, initial research from Beijing 2008 indicated that there tended to be a 'mismatch' between the top-down branding by the city authorities, and how the event and the city were experienced by visitors. The city authorities branded the event in close line with official policy, with particular reference to themes of cultural history and harmony, the international megalopolis, and a liveable (environmentally friendly) city. However, many visitors were unable to understand the ways in which these themes were projected, with the environmental aspects tending to be rated rather lowly. ${ }^{9}$ One concluding point to be made here is that soft power may only be gained when the messages of the host city or nation are clearly understood by outside audiences. In China's case, this involves ensuring that any top-down delivery of messages is closely articulated with the bottom-up experiences and perspectives of visitors and outside audiences.

Two further, critical comments might be added to the issue of soft power and the Beijing Olympics. First, we may consider what Pang Zhongying refers to as the soft power trade between China and other nations, to identify overall winners and losers. In this regard, the Beijing Games may be seen as a major attempt to tackle the substantial soft power deficit that 
China holds vis-a-vis many other countries. This negative balance is demonstrated in China's tendency to import rather than to export sport and other cultural 'products'. In addition, we should see the value of different types of soft power as varying according to political system and culture; thus, Nye has asserted that Western soft power is increased by institutions and cultural values that are considered to be weaker within China, such as autonomous civil society organizations, liberal democracy and human rights. ${ }^{10}$

Second, wherever there is the attempt to accumulate soft power there is always the possibility of soft disempowerment. I am advancing the concept of soft disempowerment here to refer to occasions in which you may upset, offend or alienate others. Thus, soft disempowerment may occur when the attempt to gain soft power backfires, so that influence and prestige are undermined rather than enhanced. The concept of soft disempowerment ensures that we should move beyond thinking only of how soft power is positively accumulated; instead, this term enables us to evaluate how social actions have positive and negative outcomes that are empowering and disempowering respectively.

The hosting of a sport mega-event such as the Olympic Games will always have both positive and negative impacts on soft power. Soft disempowerment may arise particularly as a form of reputational risk. For example, in 2010, the Gulf state of Qatar was selected to host the 2022 World Cup finals in football; since then, Western media and human rights groups have placed substantial critical focus on Qatar's treatment of migrant workers, particularly construction workers from south Asia, and its record on the social rights of women and gay and lesbian groups. ${ }^{11}$

For the Beijing Olympics, the reputational risk was centred in particular on issues relating to the environment, political freedoms, legal rights, the treatment of minority nationals, and China's role in Tibet. The latter quartet of issues was given particularly critical treatment by international media, politicians, and campaigning groups (notably Western NGOs). ${ }^{12}$ However, some Chinese politicians and media later took the opportunity to turn the issue of human rights back onto the West, for example by highlighting incidents of torture and forms of institutionalized racism in the United States. ${ }^{13}$ On the environmental issue, there had been widespread concerns, including those from the IOC, that the Games would be threatened by high levels of air pollution in Beijing. ${ }^{14}$ In response, the Chinese authorities introduced pollution-reduction measures for factories and traffic, leading the IOC to praise the hosts for having done "everything that is feasible and humanly possible to solve the situation” (Guardian, 7 August 2008).

Overall, on the soft power/disempowerment issue, two points might be made here. First, for the hosts of sport mega-events, levels of 'soft disempowerment' tend to be at their highest before and, at times, during the event; 'soft power' tends to be realised more effectively during and after the event. Beijing 2008 was no exception in this regard, with the Chinese authorities perhaps most effective in being seen to tackle directly the environmental issue. Second, as Nye indicates, we may only understand the soft power/disempowerment aspects of Beijing 2008 with reference to the wider context of China's history, modern development, and engagement with the outside world.

\section{The Beijing Olympics and mega-event security}

A third issue to consider here relates to security, and indeed the wider security legacies that remain in host cities and host nations long after the mega-event has come to an end. These 
security legacies may include, for example, new technologies, levels and types of expertise, and partnerships between public authorities and private corporations. ${ }^{15}$ The growing significance of security at mega-events is certainly reflected in how Olympic security budgets have mushroomed since two critical incidents in the United States: first, the bombing at the 1996 Atlanta Olympic Games; second, the 9/11 attacks on the Twin Towers in New York and elsewhere in 2001. Thus, security budgets rose from 1992 Barcelona (US\$66.2 million), to 2000 Sydney (US\$179.6 million), and on to 2004 Athens (US\$1.5 billion). Security spending around Beijing 2008 reached an unprecedented level - at an estimated US\$6.5 billion - which is far beyond the anticipated final totals at later summer Olympic Games in London, Rio and Tokyo. ${ }^{16}$

Commercial logics underpin the long-term security legacies that arise from sport megaevents. The Olympics provide an ideal opportunity for international security companies to converge (in both senses of the word) on host cities and nations, to showcase and to sell world-leading technologies and services to new markets. In turn these events provide both corporations and nation-states with opportunities to test or to pilot new security systems before being implemented in other public contexts. At the Beijing Olympics, almost all of the spending on security technology was directed towards business with foreign corporations such as Honeywell, GE, IBM, Siemens and Panasonic. ${ }^{17}$ Advanced security technologies from foreign companies included closed-circuit television (CCTV), surveillance systems that registered unusual crowd patterns and movements, two-wheeled electric scooters, and event tickets containing RFI (radio-frequency-identification) chips to enable the monitoring of ticket-holder movements; all of these and many other security technologies were introduced in China for the Olympics and for long afterwards. Moreover, such links also provided a crucial 'foot in the door' in terms of allowing foreign companies to pursue other security contacts and contracts in China; thus, for example, GE provided security services for Beijing's underground system and state broadcaster (in effect, this was CCTV for CCTV). ${ }^{18}$ One point that we might make here concerns how, in effect, the Beijing Olympics represented a 'glocalization' of mega-event security. On one hand, all mega-event hosts are required to demonstrate to the IOC, the competing nations, and their own publics that they have a robust and comprehensive security strategy. The distinctive aspect of Beijing's glocal security strategy centred on the scale of its security expenditure, the range of partnerships with international corporations, and the diversity of new technologies that were introduced.

\section{Post-Olympics sport legacies}

A fourth and final field to be explored in regard to the hosting of sport mega-events centres the long-term impacts and legacies on sport per se for the host city or nation. Direct sportrelated legacies might include better sports facilities that are widely used, better sports performances at elite level, a stronger sport system at elite level, the future hosting of megaevents, and greater public participation in sport and physical activity, leading to better health. Many of these legacies are, as noted, long-term in focus hence it may be too early to tell if the event has had significant impacts therein; this is particularly the case in regard to latter two potential legacies, on hosting future events and on health.

For Beijing 2008, the question of facility usage is critical; inevitably, the symbolic significance of the Bird's Nest stadium is such that particular focus will be directed towards its future maintenance and value for further events. Thus far, like many Olympic host cities, China has found it difficult to sustain the stadium through regular sports or other events. In regard to elite sports performance, it is expected that there will be some dip in performance 
from the host nation; in the case of China, this was relatively low, as the Olympic medal count slipped from 100 medals (with 51 golds) in 2008, to 88 medals (with 38 gold) at the London 2012 Olympics.

Perhaps the most useful set of insights on Beijing's post-Olympic legacy is provided by developments in the world's most popular sport, football, in the Chinese context. Three key points may be made on this issue. First, at the very top level in the men's game, China has been disappointed by the performances of the national football team. Most notably, the team has continued to miss out on qualification for the premier tournament - the World Cup finals - for 2006 (in Germany), 2010 (South Africa), and 2014 (Brazil). However, further developments within Chinese football at club level point to a much stronger long-term basis on which to build successes.

Second, the issue of match-fixing has been highly prominent in East and South-East Asia in recent years, for example as the football systems in Singapore, South Korea, and Thailand have been very seriously affected. China's football system has also been seriously affected, however the legal and football authorities have sought to demonstrate a commitment to confronting this problem. Following two years of Chinese police investigations into football match-fixing from 2009 to 2011, over fifty people were sent to prison, including leading officials, club owners, players and referees. The scale of China's response to this issue was such that one UK report indicated that, at a time when over 300 European football matches were under investigation for match-fixing, other football systems might follow a similar course of action. ${ }^{19}$ The issue of tackling match-fixing is, of course, critical in itself in the effort to establish the integrity of sport competition. But, this response is also crucial for securing two key sporting legacies from the Beijing Olympics, namely the successful construction and expansion of a national football system, and also the credibility of the nation for hosting future sport mega-events.

Third, there are signs that China is becoming more successful in creating their own international super-teams in football. The most striking example is provided by the Guangzhou Evergrande football club, which won three successive Chinese Super League championships from 2010 to 2013, crowned by winning the Asian Champions League final in November 2013. The club is propelled by the finances of the Evergrande property company, which enabled the signing of Marcello Lippi, the Italian world-cup winner, as coach, and several foreign stars, notably the Argentinian Dario Conca, and Brazilians Elkeson and Muriqui. The Guangzhou club has been more effective than other Chinese sides in recent years, notably Shanghai Shenhua, in building for sustainable success. The long-term challenge is, ultimately, to compete with the world's elite, particularly the leading European football clubs, both on and off the field of play. If this is to be achieved, a leading Chinese team will need to 'glocalize' its structure, culture and identity vis-a-vis the top football clubs in the world.

\section{Concluding comments}

The Beijing Olympics were a crucial milestone in the engagement of Chinese society with international society and with wider processes of globalization. As we have seen, the Beijing Olympics highlighted the duality of glocality within sport and within contemporary Chinese society in a number of ways, particularly through the opening ceremony and the event facilities. Glocalization is also evident in how, in its role as mega-event hosts, China has sought to acquire particular forms of soft power, and to negotiate particular challenges 
regarding 'soft disempowerment' associated with the Olympics. The increasingly important issue of event security underwent further glocalization by the host nation, with perhaps the most distinctive aspects involving the scale of security-related expenditures and the new relationships between Chinese authorities and international security corporations. The sporting legacies of Beijing 2008 may only be assessed in the long-term, though one indicator of success may lie in the glocal development of elite Chinese football, particularly at club level.

It appears unlikely that China will look again in the medium-term to sporting megaevents as a way of extending its glocalization and extension of soft power. Brazil and Russia are the other BRICS members which have won the right to host both football's World Cup finals and the Olympic Games, but there is little prospect of China having the opportunity even to bid to host the former event before 2030 at the very earliest. In that light, looking ahead, two concluding points may be made here on the intersections of sport, globalization and soft power in relation to China.

First, in the sport context, the way ahead for China should lie in an effective mixture of policies and strategies with regard to both elite and grassroots sport. In elite sport, there will continue to be a focus on sport performance, particularly as measured by results in international competition. In grassroots sport, there needs to be similar investment in sporting and recreational facilities and in the promotion of sport participation across the wider population. Such investment would contribute significantly to wider policies in promoting public health, and should provide a stronger basis for the development of young athletic talent and for securing broader public interest in sport-related activities, including engagement with elite sport teams in China.

Second, in the context of soft power, there is the question of how China may be more creative and influential at transnational level in the wider fields of non-sporting culture. In regard to the performing arts, Chinese performers may be trained to world-class level. However, in most fields of elite and popular culture, we find that soft power is best secured through a mixture of factors, including: possessing a history and culture of creative activity; advancing a commitment to the 'glocal' reinterpretation and grounding of global culture within the local or national context; securing the everyday social space for cultural activity to avoid regulation and to flourish; pursuing the increasingly important role of effective marketing and public relations activity; developing a substantial consumer culture industry, including mass media; and, generating a strong underlying 'home' field of culture, which engages cultural producers and consumers at national level, thus ensuring high levels of domestic production and consumption. Underlying much of this is a 'bottom-up' approach to cultural production and consumption, enabling cultural creativity and new cultural tastes to emerge at everyday level. If China is to secure much greater levels of soft power in regard to culture at global level, then it is crucial that these preconditions for cultural creativity and empowerment are established and allowed to thrive.

\section{References}

${ }^{1}$ R. Robertson (1992) Globalization: Social Theory and Global Culture (London: Sage); R. Robertson (1994) Globalisation or glocalisation? Journal of International Communication 
1(1), 33-52; R. Robertson (1995) 'Glocalization: Time-space and homogeneity-heterogeneity. In: M. Featherstone, S. Lash and R. Robertson (eds) Global Modernities (London: Sage), xx.

${ }^{2}$ R. Giulianotti \& R. Robertson (2009) Globalization and Football (London: Sage); R. Giulianotti \& R. Robertson (2012) Glocalization and sport in Asia: Diverse perspectives and future possibilities. Sociology of Sport Journal, 29(4), 433-454.

${ }^{3}$ Wang Ning (2010) Reconstructing (neo)Confucianism in a "glocal” postmodern cultural context. Journal of Chinese Philosophy, 37(1), 48-61.

${ }^{4}$ C.C. Chen, C. Colapinto and Q. Luo (2012) The 2008 Beijing Olympics opening ceremony. Visual Studies, 27(2), 188-195.

${ }^{5}$ J. Nye (2004) Soft Power: The Means to Success in World Politics (London: Public Affairs).

${ }^{6}$ Accordingly, we might see 'soft power' as a more neutral-sounding variant of the neoMarxist concept of 'hegemony', originally advanced by Antonio Gramsci. See A. Gramsci (1971) Selections from the Prison Notebooks (London: Lawrence \& Wishart).

${ }^{7}$ Pang Zhongying, The Beijing Olympics and China's soft power, 4 September 2008, http://www.brookings.edu/research/opinions/2008/09/04-olympics-pang, accessed 15

December 2013.

${ }^{8}$ R. Herstein and R. Berger (2013) Much more than sports: Sports events as stimuli for city re-branding. Journal of Business Strategy, 34(2), 38 - 44; B. Houlihan and J. Grix (2013) Sports mega-events as part of a nation's soft power strategy: The cases of Germany (2006) and the UK (2012). British Journal of Politics and International Relations, http://onlinelibrary.wiley.com/doi/10.1111/1467-856X.12017/abstract, accessed 12 December 2013.

${ }^{9}$ L. Zhang and S. Zhao (2009) City branding and the Olympic effect: A case study of Beijing. Cities, 26, 245-254.

${ }^{10}$ J. Nye, Soft power and the Beijing Olympics. 24 August 2008, http://www.realclearworld.com/articles/2008/08/soft_power_and_beijing_olympic.html, accessed 10 December 2013.

${ }^{11}$ See for example P. Pattisson, Revealed: Qatar's World Cup 'slaves'. The Guardian, 25 September 2013, http://www.theguardian.com/world/2013/sep/25/revealed-qatars-world-cupslaves, accessed on 17 November 2013.

${ }^{12}$ See for example R. Spencer, Beijing Olympics 2008: Tibet policy angers IOC chiefs. The Telegraph, 25 June 2008, http://www.telegraph.co.uk/news/worldnews/asia/china/2193545/Beijing-Olympics-2008Tibet-policy-angers-IOC-chiefs.html, accessed on 19 December 2013; S. Brownell (2012) Human rights and the Beijing Olympics: Imagined global community and the transnational public sphere. 63(2), 306-327.

${ }^{13}$ China hits back with report on US human rights record, 26 February 2009, http://english.people.com.cn/90001/90776/90883/6602049.html, accessed on 8 December 2013.

${ }^{14}$ G. Farquhar, Smog casts a cloud over Beijing, BBC News, 17 August 2007, http://news.bbc.co.uk/sport1/hi/other_sports/6950101.stm, accessed on 3 December 2013.

${ }^{15}$ R. Giulianotti and F. Klauser (2010) Security governance and sport mega-events: Towards an interdisciplinary research agenda. Journal of Sport and Social Issues, 34(1), 49-61. 
${ }^{16}$ B. Houlihan and R. Giulianotti (2012) Politics and the London 2012 Olympics: The (in)security Games. International Affairs, 88(4), 701-717.

${ }^{17}$ Y. Yu, F. Klauser, and G. Chan (2009) Governing security at the 2008 Beijing Olympics. International Journal of the History of Sport 26(3), 390-405.

M. Bristow, China's Olympic security dilemma, BBC News, 12 March 2008, http://news.bbc.co.uk/2/hi/asia-pacific/7292025.stm, accessed 20 January 2012.

${ }^{18}$ K. Bradsher, China finds American allies for security, New York Times, 28 December 2007, http://www.nytimes.com/2007/12/28/business/worldbusiness/28security.html?pagewanted=al $1 \&$ r $=0$, accessed on 5 December 2013.

${ }^{19}$ R. Simons, Lessons Europe can learn from China's match-fixing scandal, BBC News, 6 February 2013, http://www.bbc.co.uk/news/business-21333610, accessed on 8 December 2013. 